\title{
Towards more flexible approach to governance to allow innovation: The case of UK infrastructure
}

\section{Introduction}

It is commonly understood that every organisation, initiating projects and/or programmes, should have its own form of corporate governance (Müller, 2011; Winch, 2014). The Association for Project Management (APM) Governance Special Interest Group (SIG) defines governance as a "set of policies, regulations, functions, processes, procedures and responsibilities that define the establishment, management and control of projects, programmes and portfolios. It gives an organisation the required internal control, while externally, it reassures stakeholders that the money being spend is justified" (APM, 2006, 2011, 2017). The Project Management Institute (PMI) defines governance as "the framework, functions and processes that guide activates in projects, program and portfolio management. In organizational project management (OPM), governance provides guidance, decision making and oversight for the OPM strategic execution framework." There are different definitions available of corporate and project governance in the project management literature (McGrath and Whitty, 2015). It is commonly understood that corporate governance sets the rules for making decisions that shape relationships and actions in an organisation (Mayer, 2012; Müller, 2011; Müller et al., 2017; Too and Weaver, 2008). Project governance is commonly seen as the arrangement for overseeing the projects; it is a way of engaging senior people in the project and get their 'buy-in' and ensure the decisions can be made (Miller and Hobbs, 2005; Too and Weaver, 2008).

Winch (2014) proposes a conceptual framework by setting out three principal organisational domains - owners and operators, supplier project-based firms, and projects and programmes - and identifying their interfaces - commercial, resources, and governance. 
Winch and Leiringer (2016) further propose that a set of governance capabilities are required to manage the interface between the owner organisation and the temporary project organisation that is set up to deliver the investment. They discuss assurance, project coordination and asset capabilities as key governance capabilities. McGrath and Whitty (2015, p. 755) are in agreement and define governance as "the confluence point where the competing interests of the temporary project organisation and the more permanent parent organisations must be resolved". To date, little is known about this governance interface: "We still know little about how governance arrangements actually work in practice, and which approaches to assurance are most appropriate in which contexts" (Winch and Leiringer, 2015, p.7). Of particular interest is the interaction between narratives of governance as mobilised by practising managers in owner organisations and the projects in which they invest (Biesenthal and Wilden, 2014).

Our focus is on understanding how the meaning of governance is socially constructed by senior managers from both permanent owner organisations and temporary project organisations through the use narratives. Narratives are often spoken, but there are other forms of narratives such as textual and visual. These are often reproduced in policies and reports, corporate websites, or in other externally-facing materials (videos, pictures). Being responsible for formulating and disseminating organisational vision and strategies, managers play an active role in the construction of such narratives (Sonenshein, 2010).

Of further note is that the Infrastructure and Projects Authority (IPA) has developed a Project Initiation Routemap module on governance with the aim of improving infrastructure delivery. IPA (2016) emphasise that for infrastructure projects "good governance is about a balance between the natural desire of sponsor(s) to retain control, and the need of the delivery team to have sufficient freedom to allow it to manage the risk to meet the project objectives". Yet, the ways in which this balanced approach to governance as a duality of control/freedom 
works in practice remain under-explored. There is a real problem in practice between implementing deterministic and prescriptive models of corporate governance against the need for flexibility and innovation. This paper explores this and the related issue of the extent to which the governance interface between permanent owner organisations and temporary project organisations represents opportunity for innovation. This is the gap that this research study addresses.

The following overarching research questions will be answered:

RQ1. What are the narratives of governance where owner organisations interface with the temporary project organisations that they initiate?

RQ2. To what extent does the governance interface in project organising represent opportunity for innovation from the narratives mobilised by managers?

These questions contribute to the project management literature by addressing the literary gaps in governance capabilities of owner organisations, highlighted by Winch (2014) and Winch and Leiringer (2016). Furthermore, adopting a narrative approach addresses the gap in narrative inquiry in the project management research. There is a growing use of narrative inquiry by scholars to understand project organising (Boddy and Paton, 2004; Enninga and van der Lugt, 2016; Havermans et al., 2015). However, there is little theoretical consistency in defining a narrative. In this research, narrative is defined as unique discursive constructions that provide essential means for maintaining or reproducing stability and/or promoting or resisting change in and around organisations (Cunliffe et al., 2004; Vaara et al., 2016).

This paper has analysed and reviewed the textual narratives of governance as mobilised in institutional reports (APM, 2006, 2011, 2017; IPA, 2016) and voiced narratives 
of governance as mobilised by managers in permanent owner organisations and temporary project organisations based on narrative interviews.

\section{The meaning of governance}

Despite various formulations of the meaning of governance, it is often associated with the words like "steer", "control", "decisions", "formal", "influence" and "manage". There is a growing body of research trying to investigate different aspects of governance at policy, organisational, programme and project levels. Much research focuses on examining success factors influencing "good" governance at these levels (Abednego and Ogunlana, 2006; Joslin and Müller, 2015; Müller et al., 2015) or measuring variables (Chang, 2015; Ping et al., 2015). Klakegg et al. (2008) clearly recognise that governance operates at multiple levels and is typically associated with regulatory structures.

From the reviewed literature, governance can be defined as a set of arrangements, both formal and informal, processes and structures that provide a framework for the successful delivery of projects. Different mechanisms are established by owner organisations in order to assure a successful outcome of their projects, these processes form project governance (Biesenthal and Wilden, 2014). Müller (2009, p. 4) defines it as follows:

"Governance, as it applies to portfolios, programs, projects, and project management, coexists within the corporate governance framework. It comprises the value system, responsibilities, processes and policies that allow projects to achieve organisational objectives and foster implementation that is in the best interests of all the stakeholders, internal and external, and the corporation itself".

Müller et al. (2016) further define governance as the value system, structures, processes and policies that allow projects to achieve organisational objectives. The different 
governance frameworks across the organisation need to be related and therefore project governance must comply with the corporate governance of the firm. According to Müller (2011) project governance aims to ensure the consistent and predictable delivery of projects within the limitations set by corporate governance. He describes a set of institutions inside the organisation that ensure this alignment of governance frameworks across the firm. The Board of Directors, among setting the strategic objectives and other responsibilities, also defines the establishment of PMOs (Project Management Offices), whose role is to guide the project to comply with the set objectives in order to achieve the desired tactical and strategic performance expected from the Board, and all the stakeholders involved. Müller et al. (2017) further explore the role of governance and governmentality in project and organisational success. In their study the survey conducted with 121 respondents supports the model of governance being positively related with success at project and organisational levels.

Cardenas et al. (2017) further propose a project governance model that includes relevant variables for measuring project governance in construction projects. Ma et al. (2017) argue that an integrative mechanism of corporations, the Government, and the public is essential to facilitate and maintain societal governance, creating shared and sustainable value for all stakeholders involved in the lifecycle of the megaproject. Townsend et al. (2017) further demonstrate how organisational governance has evolved from hierarchical structures to relational networks through the ways project-based alliances are increasingly employed by automakers as part of their innovation strategy. Chakkol et al. (2018) explore the governance of collaboration, arguing that successful delivery of complex projects requires flexibility to respond to customer requirements, and the governance structure can be replicated across multiple projects. They distinguish between contractual and relational governance. Contractual governance refers to formal and legally enforceable inter-organisational agreements. Relational governance is informal and multi-dimensional which includes 
encouraging personal means of social interaction through informal project meetings, job rotations, shared events. Yet, Chakkol et al.'s (2018) data is limited to the primary contractors, leaving space to explore the governance interface from the perspectives of managers who work in owner organisations which play an important role in setting contractual and relational governance in projects. Benítez-Ávila et al. (2018) further address the interplay between contractual and relational governance in public-private partnerships building upon neo-institutional theory, yet excluding the wider institutional, cultural and policy context that may affect the governance approaches. Brunet (2018) conceptualises governance-as-practice based on processual and practice studies. He explores enactments of multileveled governance and performative practices. But Brunet (2018) has not focused on examining people's perceptions and interpretations of governance through their temporal governance as a promising venue for future research. Brunet and Aubry (2018) further investigate the process of translation of an institutionalised governance framework as adapted to a major project in practice using a case study of one public infrastructure project in the health sector in Canada through the lens of actor-network theory. They demonstrate the ways actors translate and enact those governance frameworks in practice. This article builds upon their work in order to explore further the ways governance frameworks are translated through narratives and enacted in practices from the perspectives of senior managers in the UK infrastructure owner organisations and major projects.

\section{The "strong owner" and governance capabilities}

The literature on project governance suggests that "individual projects are subjected to governance by private and public owners" (Ahola et al., 2014, p. 1325). Winch's (2014) definition of an owner and operator is best understood through description of an energy utility company. The company's core business is delivering energy to customers through energy networks. However, the company also undertakes projects to develop or maintain 
these networks, making them the owner and operator of these networks; any projects undertaken, such as building power stations, "are only of value to the extent that they support that core business" (Winch, 2014, p.723). Winch's concluding remarks in both this paper and later research (Winch and Leiringer, 2016) call for further investigation into owners and operators and their governance capabilities. Winch and Leiringer (2016) proposed that there is a series of project capabilities that an owner and operator should possess including: commercial capabilities that are utilised in the commercial interface; strategic capabilities that assist the implementation of investment projects, and governance capabilities that are required to manage the interface between the owner and operator and the projects and programmes. Governance capabilities include the activities and responsibilities of the owner and operator with the specific projects and programmes being developed, such as assurance capabilities (through control mechanisms throughout the whole progress of the project), project coordination capabilities and finally the capability to manage the transfer to operations. Winch and Leiringer (2016, p.7) outline a key consideration to be taken into account when adopting governance capabilities. This is that "oversight" - "the ability of the owner organisation to monitor project processes within its capability scope" - can become overbearing, and that there is a balance to be struck between governance capabilities that are robust, but also do not restrict the performance of the project organisation. This provides a framing for exploring narratives of governance from the perspectives of managers who work in permanent owners and operator organisations and temporary project organisations.

Other relevant studies include Zwikael and Amyrk (2015) who propose a project governance model which includes two key players: the project owner who represents the project funder's interest in the project and the project manager. Samset and Volden (2016) further reaffirm that project manager's need to be concerned about governance aspects and front-end project definition. The question posed by these authors is what would be the 
optimal mix of regulations, economic means and information in improved governance regimes. Effective project governance and benefits management are seen to have strong impact on project success (Musawir et al., 2017).

Yet, there is another important capability - the innovation capability of owners and operators that is not explicitly addressed by previous research. The role of owners in driving innovation in the supply chain is becoming increasingly recognised (Brandon and Lu, 2009; Orstavik et al., 2015). To date, little is known about the relationships between governance and innovation capabilities at the interface of owners/operators and projects/progammes. Winch (2005) proposed top-down and bottom-up models of construction innovation: new ideas adopted by firms and implemented in projects (top-down), or result from problemsolving on projects and adopted and learned by a firm (bottom-up). This is consistent with his earlier work about a process of interactions between the innovation superstructure (clients, regulators and professional bodies) and infrastructure (specialist suppliers and builders), calling for further exploration of innovation processes at the level of individual firms and projects. "Almost all innovations in construction have to be negotiated with one or more actors within the project coalition. An individual firm's ability to do this will be strongly influenced by its role within the industry" (Winch, 1998, p. 273). The governance aspect here is the capability of the permanent owner organisation to stimulate the temporary project organisation to innovate.

Some scholars attempt to combine project governance and innovation management literatures. For instance, Wu et al. (2017) assume that the performance of cooperative innovation projects is one of the topics of project governance. They argue that the governance of inter-organisational innovation projects remains under-explored and ambiguous. The formation of formal contracts and relational trust effect cooperative innovation projects performance. Zerjav et al. (2018) emphasise that owners/operators rely on dynamic 
capabilities to manage project capabilities consisting of a portfolio of innovation projects. Established project capabilities can be revised to keep up with changing conditions and emergent innovations on projects. We argue in this article that in order to acquire the innovation capability, it is necessary that the whole owner governance framework possess a certain degree of flexibility to accept unexpected changes when dealing with high complexity projects surrounded by sometimes a difficult and uncertain environment, and take risks to achieve value. This will allow project managers more possibilities for the successful implementation of innovations that will bring additional benefits to the owner/investor firm; and even improve whole industry performance.

\section{Methodology}

\section{Narrative approach}

This research uses insights and methods borrowed from narratology to obtain a better understanding of narratives of governance as mobilised by practicing managers. Narratology is the theory and study of narratives (Czarniawska, 1997). It is a form of qualitative research that uses field texts, such as reports, conversations, interviews, pictures and video as the unit of analysis to research and understand the way people create meaning (Vaara et al., 2016). In recent years, narrative perspective has been increasingly used in project management studies (Green and Sergeeva, 2018; Müller et al., 2015; Sankaran, 2018). Although narratology has made significant advances in organisational and management studies, scholars have not yet unleashed its full potential, especially in terms of empirical research. The main method in narratology is open ended and unstructured interviewing techniques which allow the narrator to produce narratives. Interviews and observations thereby provide cues and nuances into narratives and their interactions (Frandsen et al., 2017). Narrative interviews are specifically designed to encourage participants to tell micro perspectives of practicing managers about their experiences in their own way (Mishler, 1991). The selected narratology methodological 
stance helps to understand how practising managers make sense of governance through narratives they construct (Biesenthal and Wilden, 2014; Müller et al., 2015).

\section{Data collection and analysis}

In order to learn more about the governance interface in the project organising where owner organisation and temporary project organisation interact (Winch, 2014), we chose multi-case approach rather than a single case that is limited in providing general understanding (Zerjav et al., 2018). In this context, a multi-case approach means that the interviewees all represent different UK infrastructure organisations. Our empirical data has been collected from twenty-five face-to-face narrative interviews with senior managers working in UK infrastructure, within permanent owner and operator organisations and temporary organisations (megaprojects). This was combined with the analysis of textual narratives represented in institutional reports (cited in the introduction) and attendance at a number relevant events on governance (notes being made by the researcher). Around half of the interviewees were from permanent owner organisations and another half from temporary organisations which allowed us to better understand the governance interface from both perspectives. A few interviewees came from other organisations (project-based firms or consultancies) who have been in the industry for a long period of time and have experience working in permanent owner organisations and temporary projects and programmes. The reasoning behind choosing this approach is because our interest lies in exploring narratives mobilised by practising managers within owners/operators and projects/programmes, and the ways they respond to the policy level narrative mobilised in institutional reports (APM, IPA, PMI).

Senior managers were accessed through the researcher's involvement in the APM Governance SIG, and the Project 13 stream on Capable Owner. The stated purpose of the APM Governance SIG is to be the UK focus for those who are interested in governance in 
project management. Project 13 is an industry-led initiative to improve infrastructure delivery models based on whole life outcomes in operation and support a more sustainable, innovative and highly skilled industry. The researcher established contacts by engaging with these initiatives.

The interviewees were typically in senior management positions and have a number of years of experience. They were initially selected on the basis of their interest in the governance interface in permanent owner and temporary project organisations and their job titles typically related to governance (e.g. asset management, risk and innovation). The interview questions were deliberately generic and open-ended. In contrast to semi-structured interviews, narrative interviews are designed to encourage interviewees to tell stories about their understanding of governance and how they practice it. The interviews lasted a little over an hour and were typically held in the interviewees' corporate offices. Table provides background information about the interviewees, their organisations, and the interview length.

Please insert Table 1 here

The interviews were transcribed in full by the author, thereby aiding subsequent analysis. The analysis method primarily comprised repeated detailed reading of the transcripts. The analysis was analytically sensitive to identifying narratives of governance as mobilised by practising managers when drawing from their own experiences. The plot is a crucial part of a narrative that ensures meaningfulness and coherence. During the narration there should be an identifiable voice (Czarniawska, 1997; Frandsen et al., 2017). Voiced narratives may contain a sequence of events or discursive representations that embodies coherence or unity of purpose. The analysis involved multiple readings of the transcripts 
resulting in several iterations between the entire dataset and emergent findings (Alvesson and Kärreman, 2007). Table 2 (see after the analysis) provides details of the narrative analysis including the identified narratives of governance as mobilised by the interviewees, exemplary codes and exemplary quotations.

\section{Findings}

\section{Making sense of governance}

There has been an agreement among the interviewees that governance means different things to different people. There has been also an agreement that owner organisations play an important role in defining the need for the projects and programmes in setting the governance framework:

"For me the key thing in relation to governance is ability of the client or the owner organisation to properly define what it needs and why. Maybe it needs the help of supply chain to do that. Because we can do that well, we create the conditions to innovate around that articulated need. What the client can do is to articulate the need. I know it is Tiers and Tiers when you get to the project, how the project is managed. Some of it is to make sure the sponsor function or the owner function is active and is capable to make sure that need is articulated, and is transferred to individual projects." (Director External Affairs and Strategy, Institution of Civil Engineers)

The above quotation emphasises the crucial role of owners and owners' governance capabilities to clearly articulate the need for individual projects they initiate. It is owner organisation's responsibility to create and articulate a narrative about the project mission to all stakeholders involved in the project execution. The argument is that well-articulated need from the owner creates the conditions for innovations. 
Those interviewees from permanent owner organisations tend to talk in the context of a corporate governance:

"I tend to talk about corporate governance. Governance is something that you can write down in terms of reference for. You are very clear in terms of what is necessary to meet whatever the governance level that has been applied. And then you run that governance process through to those in terms of reference and then the target in the process." (Director of Asset Management, Water and water recycling services to domestic and business customers).

Furthermore, the interviewees tend to distinguish between governance at corporate level and at project and programme level and talk about the integration and alignment between the two:

"There is a fairly clear governance process at project and programme level. It is defined through a series of milestones or gateways. It is a gateway governance process where water company approves and authorises investment but with the alliance solutions. It is pretty integrated process. Those gateways have been recognised as governance gateways for the client and also for alliance. Corporate governance and project governance should be part of the same structure. They have to be integrated somewhere. Any decisions here have to be aligned with the corporate governance decisions as well." (Director of Infrastructure and Non-Infrastructure Design and Build Services)

Governance at project or programme level was most commonly associated with decision making. One such example is as follows:

"To me governance is the ability to facilitate decision making. That is all we are really trying to do. All we ever do as a management team, either at project level or a programme level, all we really do is make decisions." (Programme Control Director, Transport infrastructure major project) 
He further reinforced that there are two ways of making decisions. One way is to rely upon one individual, usually the CEO, who might be the smartest person in the world and hopefully makes the "right" decisions. Whereas the governance framework provides the ability to recognise that for certain decisions one individual is not enough and there is a need for a quorum of people who ensure that everything that has an impact on the decision is considered. In owner organisations two layers of governance were usually distinguished: formal corporate governance and operational governance. Corporate formal governance was recognised as the collective power of a group of people rather than an individual. For example, if the minimum number of people is there, but a senior person like a programme director is not present, then the decision can still be made. Operational governance was referred to exercising authority that is delegated to individuals by a board. At the core is a framework that facilitates decision-making and then gives the ability to record decisions. Managers are able to go back and have a look at the archives and understand how they did come up with the decisions. They can see exactly what was said and what was the justification for that decision.

Several interviewees clearly distinguished between governance and assurance. Whilst governance referred to empowering people to make decisions, assurance was seen as a more personal process of making decisions:

"Governance and assurance are just mixed up. Governance for me is I want to empower people to make decisions. I want to make sure when they make decisions they do not make wrong decisions. It is my job to sit above that and be accountable. Assurance for me is personal: how you assure yourself that this is working." (Programme Director, Airport infrastructure operator) 
Of particular interest is the way a Programme Director defined governance as a way of empowering the project team to make "right" decisions; assurance as a personalised way of assuring yourself that everything is working.

It was further seen that formal assurance is needed when something is not going as planned in projects (e.g. time and budget overruns). Senior managers need to understand governance and assurance processes:

"Typically, the work in projects is allocated to people who are good at performing the tasks in comparison to a "command and control" model. However, there are times when something affects health and safety, or impacts significantly on stakeholder, or results in cost-overruns these are the indications of a need for a formal check point. For senior managers it is important to understand at what point they need people to ask the permission to do things differently." (Head of Innovation, Public Transport Infrastructure project)

\section{The need for a "good" corporate governance}

"Governance should be good governance" - this is a common narrative mobilised in most interviews. It needs to be smart and timely (e.g. meaning on a weekly-basis). In most organisations the Board of Directors meet at least monthly to apply governance. The senior managers interviewed are in positions of turning down proposals for innovations from the employees (e.g. project teams) because they have not met the specified criteria in the governance framework. They feel obligated:

"To me governance is really important not only in protecting of parties because good governance is about giving individuals not just cooperative confidence that they can and should progress. So, a difficult decision, whether it is good news or it is bad news, brought to the right governance body at the right time allows things to progress." (Director of Asset Management, Water and water recycling services to domestic and business customers). 
"In the absence of formal governance, you only end up with one thing and that would be chaos.” (Programme Control Director, Transport infrastructure major programme)

There was agreement among all interviewees that there is a need for formal and clear project governance. The Chairman of a UK-based multinational public transport company has observed throughout his career many projects that went wrong because of unclear governance structure:

"In terms of governance, any projects that do not sort out its governance structure as number one task at the beginning is going to be in trouble. You have got to have a clear governance. You have got to have clarity of the means by which decisions are made, what role of the client board, even it may not be seen very often, but it needs to know what it needs to be involved in, what decisions it is going to be making. And it has got to give devolved powers to each representatives, which we traditionally called project sponsor."

The front-end of projects is seen as critical for clarifying project governance that has an impact on project success. The roles and responsibilities need to be clearly defined at the front-end of projects.

\section{Governance flexibility}

"The more you want innovation in projects as a client, then the more you need to be open about it." (The Chairman of British multinational public transport company)

The best form of corporate governance is seen to be a very strong framework and maximum flexibility within it. It is a strong framework that permits people to operate and do their best; and when they go outside that framework, there is a governance boundary that says people need permission or they need authority to do that. It does matter if it is corporate innovation, it is the same for everyone. It could be financial, but it could also relate to hiring people; it 
might be how long you let the contract for. When owner organisations need to make fundamental decisions about investments it goes to the Board of Directors. Organisations that are recognised as capable owners keep the governance to minimum to allow decisions to be made for opportunities for innovations:

"Within [name of owner and operator organization] we have little governance. We purposefully kept it light. That gives us an ability to make decisions when they are necessary and it is usually down to few key individuals who have to come together to allow decisions. They have a Board. We have the programme board and ultimately that is it; we have working groups, steering groups. Broadly speaking, if we need to make a fundamental decision around how we create a capability we need to deliver challenge and we have to make a huge investment it will go to that Board. The trick is that to keep that governance to the minimum that is required." (Head of Projects, Leading owner and operator infrastructure firm).

The biggest "enemy" is seen to be a micro-governance when it is difficult for people to get a permission to do things differently. There are two possible responses from people. First, people do not bother and they just do not do it: "I have a good idea but it is too difficult for someone to accept it. I just not going to share it". Second, people may either ignore the governance because it is too difficult: "I am radical. I know it is right things to do. I am going to do it and blow the consequences". Both of those are seen as "negative" - people get frustrated; they either break the rules or they just do not come up with good ideas. But if an organisation has a corporate governance framework that people are coming up with ideas that go brilliantly, and when they have big challenges or amazing ones, they think: "Ok, there is a governance boundary. They have supported me there. It is not unreasonable for me to go through several stage process to take this idea further". The Strategic and Operation Director from an urban wastewater infrastructure project organisation has shared his view on the revising governance with the arrival of new CEO: 
"I just think governance is quite clunky and clumsy in most companies. In [name of the megaproject] we loved governance when [name of CEO] took control as CEO of [name of the megaproject] independent regulation contract with shareholders, he was able to re-visit governance. We do not want previous governance. We want to make it a broad framework and maximum flexibility within it. That makes people more respected, more trusted. People feel respected and trusted. You get the best out of it."

The above quotation shows the way governance has been revised with the arrival of new CEO who allowed higher degree of flexibility, respect and trust among people.

\section{Governance and innovation}

There has been made a strong connection between governance and innovation by all interviewees. There has been an agreement that too tight corporate governance is a barrier to innovation:

"I think that having too tight governance framework can stifle innovation. When you specifying the criteria for something to be build, or specifying what people can do and cannot do without asking for a permission, I think it stifles innovation." (Strategic and Operation Director, urban wastewater infrastructure temporary owner)

Too constrained corporate governance was also seen to allow only incremental innovations rather than radical step changes that owner organisations strive for:

"People will always revert back to what their interpretations of innovations are in a governance situation. And often they are operating in little time to understand the detail. If you are not careful the decisions in a governance environment too constrained will default to the middle ground; which the best innovations are not in the middle ground, it is totally extreme. Equally, depending on how governance structures are constituted often you end up with people... some people in governance organisation can know what you are talking about, 
other people will not know what you are talking about, although they have limited knowledge they will naturally default to going with what have been existed before or defaulted to a middle ground where it is an average kind of innovation in comparison to innovation that could be really a step change. Governance is key. The appetite for risk needs to be clearly understood in the environment where innovation either in product or in processes being thought. In a place like this you have a capable owner. There is a good opportunity to make innovation really work." (Delivery Director for large infrastructure programme, Leading owner and operator infrastructure firm).

Of particular note that the interviewee emphasized that the governance is key for step change innovation. In capable owner organization it is seen a good opportunity to make innovation work.

When funding is required for innovative ideas to be developed further and implemented in projects, there is a process of getting permission, often defined as corporate governance. All managers interviewed highlighted that corporate governance should be "relaxed" and flexible to allow innovation. Of further note is that if failures happen there is a need to learn from it and move faster to new projects - this is particular area where improvements can be made:

"There is always governance. In large organisations like mine it can be tough. You always need to get different approvals; for funding you always need approval. That is something that need to be reviewed. It could be too rigid because sometimes governance comes from the experience of managing projects, I think it needs to be more relaxed when you talk about innovation, I would say. What I say before about failure, that is an area where we need more scope to be able to fail and move quickly. Innovation is about getting in front of the competitions, you need to go quick, obviously within your mission, but sometimes governance can be stopper. You need to have it, you need to have some direction, you need to be more relaxed." (Head of Innovation, Global operator of services and infrastructure) 
It was further reinforced that governance should allow people to fail at innovation:

"You got to allow people a space to fail innovation. With innovation you have got to say, there is a pot of money, we are going to risk that with innovation. We might lose the whole lot, but it is fine. We might get one or two things out of that which is going to make a huge amount of money. You can sign it as a loss. We are not expecting to get it from that gambling effectively. You need to gamble - you then sign it off as a loss. That sense of risking and taking some gamble with your ideas and make it work can bring huge success. But it is also that ability to fail from the first point. I think it is governance that says we give you permission to go and fail. We hope you come up with successful idea. But we understand that it is a risk, you can fail it. It is where Innovate $\mathrm{UK}^{1}$ coming in terms of risk, financing risk. You can use Innovate UK funding to actually finance a risk." (Knowledge Transfer Manager, Networking organisation for Innovate $\mathrm{UK}^{1}$ )

The link between governance and innovation was demonstrated by the specific example of the ways scheme has been approved after improvements have been made suggested by the corporate governance Board:

"Somebody came in and said: I have got brilliant scheme: it is $30 \%$ lower on Capex than it would have been 5 years ago. It is $40 \%$ serving on Opex that we would otherwise would have to charge, and this is a scheme that have got 30,000 new population added to it. And I have saved $30 \%$ of carbon. What would governance say? Governance would have said: Thank you, but you have not achieved your targets. Now go away and find a way of doing it. It is the target that you have to achieve $50 \%$ of carbon. The reason I tell this story is that was 8 months in from the day we switched to include carbon, 1 April 2010. Governance has been

\footnotetext{
${ }^{1}$ Innovate UK is a government-sponsored body that provides innovation funding for business that covers the costs of risks associated with an innovation.

${ }^{2}$ Dragon's Den is a British television series in which budding entrepreneurs get three minutes to pitch their business ideas to five multi-millionaires willing to invest their own cash
} 
applied up to that point and when somebody asked, they have been sent to find the right answer. This team went we have a good story, but not good enough yet. We are going to cut it for the governance until we have met all the criteria. When they met the criteria, another $£ 3$ mln, another $10 \%$ from Opex, their Opex was lower for the current 30,000 population and they were $60 \%$ less of their carbon. Guess how that team felt about that? Guess how that story has been into folklore? That was governance that was not accepting that has been brought forward, being demanding that solution can be achieved, and when it is achieved being willing to promote it and the team knowing with confidence that they have the outcome." (Director of Asset Management, Water and water recycling services to domestic and business customers)

Of particular note is the way the scheme was not accepted at the first instance, but only after improvement it has been approved. This demonstrates the ways governance can be more flexible. There is also recognition that once the solution has been achieved, a story can be shared and promoted to the wider audiences.

There have been a number of specific examples of the governance mechanisms for allowing innovation. Major programmes tend to organise communication events, modelled on Dragon's Den ${ }^{2}$, where organisational members get three minutes to pitch their innovation ideas to a board of senior managers who make decisions about their funding. A thematic, focused approach to such events leads to more innovative ideas:

"We have an innovation process. I personally think the innovation process is really important based on my previous work. There is of course an element of creativity in innovation, but I still think, there have been misunderstandings and misrepresentations of it around randomness, whereas best innovations probably come from when you have innovation process or when you have like a structured challenge. It is no coincidence when we have a structured challenge, like coms campaign centered around either a specific challenge or 
specific event we have more ideas because people are able to focus. You cannot just say to someone give me an idea, it is much better to say, here is this list of challenges that we need to solve that we are facing, what do you think we can do to solve them. Even like here is a budget, there is certain amount of budget in the innovation forum, but people know that you are more likely to, if you apply between $10-60 \mathrm{~K}$, you are more likely to get funding. Even that provides an example to people. It is very hard to start with a blank sheet." (Alliance Innovation Manager, Urban wastewater infrastructure megaproject)

Table 2 summarises the identified narratives about governance as mobilised by the interviewees, together with their description, example codes and quotations.

Please insert Table 2 here

\section{Discussion}

In this paper narratives of governance as mobilised by senior managers who work in permanent owner and operator organisations and temporary project organisations are examined. Through the narrative interviews the practice of governance is explored from the perspectives of senior managers. Senior managers socially constructed the meaning of governance through narratives. The meanings of governance emerge through narratives about interplay of control/flexibility (Chakkol et al., 2018; Müller et al., 2017), formal/informal (Biesenthal and Wilden, 2014; McGrath and Whitty, 2015), relational/contractual (Townsend et al., 2017), order/chaos (Simard et al., 2018). These interplays have important implications for constructing the meaning of governance by the senior managers interviewed. These also broadly feed into the assembly of dynamic governance capabilities in owner/operator organisations (Winch and Leiringer, 2016; Zerjav et al., 2018). To date, little is known about 
the ways owner and operator organisations build and enhance their governance capabilities. In this paper the empirical findings demonstrate the crucial role of the owner organisations and their corporate governance capabilities to clearly define and articulate the needs for projects and create conditions for innovation around the articulated needs.

The empirical findings indicate the dynamic nature of governance structures and capabilities in permanent owner and temporary project organisations. From the perspectives of the senior managers interviewed, governance structures and procedures can be changed, revised, and updated over time. This happens through emergence of new regulations, policy procedures, dialogue and negotiation between senior managers and project managers in permanent and temporary organisations. It is evident that major project organisations gain more freedom as they move throughout the life-cycle in making own decisions in comparison to stricter governance at the front-end. This allows more flexible approach to governance that can stimulate innovations in projects.

All managers interviewed emphasised a strong connection between governance and innovation. The empirical findings demonstrate that the flexible and balanced approach to governance is a useful framework for innovation and performance improvement. The governance interface in the project organising (Winch, 2014) provides an opportunity for innovation. Whilst a too tight governance structure stifles innovation, a more "relaxed" and flexible approach stimulates innovation. A number of specific examples have been shared by the managers interviewed. As innovations are associated with high risk and uncertainties, it was argued by senior managers interviewed that the culture of owner organisations should allow people to fail and learn from failures in order to motivate people to innovate in the future. This contributes to the emergent literature that links governance with innovation $(\mathrm{Wu}$ et al., 2017), and calls for further research into the interrelationships between the two. It also contributes to conceptualisation of governance-as-practice focusing on micro-perspectives of 
managers and their day-to-day experiences articulated in their narratives (Brunet, 2018; Brunet and Aubry, 2018).

\section{Conclusions}

\section{Contribution to knowledge}

The governance interface in project organising is explored in this paper (Winch, 2014). There is a growing interest in governance in project management research (Hjelmbrekke et al., 2014; McGrath and Whitty, 2015; Müller, 2011; Müller et al., 2016), yet there is a lack of theoretical consistency and empirical investigation. A number of theories have been applied to better understand governance in project organising: agency theory, transaction cost economics, stakeholder theory, shareholder theory, stewardship theory and resource dependency theory (Biesenthal and Wilden, 2014). A narrative perspective offers an opportunity to explore how the meaning of governance is constructed through narratives mobilised by practising managers in the first instance. This article contributes to the emerging research into governance by examining the ways narratives interact between the level of the firm and projects, from the perspectives of senior managers. It reinforces the role of "strong capable innovative owner" in creating the governance framework to allow innovation and continuous improvement at the level of supply chain, programmes and projects (Ahola et al., 2014). We contribute to the work on governance and innovation capabilities in project organising (Winch and Leiringer, 2016). At present, there is scant research that examines the connection between governance and innovation (Wu et al., 2017). We demonstrate that the governance interface between owners and operators and projects and programmes provides an opportunity for innovation. The findings show that the flexible and "relaxed" approach to corporate governance is a useful framework to stimulate innovation in projects and programmes. A number of examples of communication events, hubs, forums, 
innovations days were shared by the interviewees which demonstrate the ways more flexible approach to governance works in practice.

In summary, the contribution of this paper is threefold: (1) it provides empirical data on the practices of governance; (2) uses narrative enquiry to collect the empirical data on practice of governance; and (3) identifies of the importance of innovation in the governance interface by showing the governance mechanisms by which permanent owner organisation stimulates innovation by the temporary organisations.

\section{Practical implications}

The practical benefits of the research study to the project management community is a better understanding of the alignment between corporate and project governance, the important role of leadership and their narratives in governing processes, and the impact of strong governance on innovation, organisational performance and project deliverables. There is generally a strong alignment between the narrative of governance at industrial policy level as represented in institutional reports (APM, IPA, PMI) and those mobilised by practising managers. The narratives of governance detail the ways flexible approach to formal governance allows innovation and performance improvements. Capable owners play key roles in the process of creating corporate governance that allows innovation to emerge in the supply chain, and on projects and programmes. The narratives constructed by practising managers inform the industry agenda and share the ways governance is defined at the industrial policy level. The current research moves the current debate on governance framework forward by offering new insights and practical recommendations:

- Governance is an ability of the owner organisation to define what it needs and why;

- Governance is an ability to empower people to make decisions or to facilitate decisions; 
- Governance is always formal and has to have clarity of the means by which decisions are made, yet informality also need to be considered;

- As an owner, the more you want innovations in projects, the more you need to be open about it;

- Flexible and relaxed approach to governance facilitates innovations;

- Governance framework should permit failures.

\section{Limitations and future research directions}

Future research could adopt different methodological and theoretical stances to understand the governance interface in project organising. The current research found the need for governance to be adjusted through the life cycle of projects, yet to trace this adjustment will require a more longitudinal research approach. The ways narratives of project governance change throughout time maybe based on ethnographic theory building approach. Multiple case study-based research could further demonstrate how formal and informal governance integrate and change over time. Of further interest are the relationships between the blend of contractual and non-contractual governance relationship and innovation. It is of practical value to better understand how to improve governance and innovation capabilities in owner and operator organisations. Of further interest is to explore the relationship between governance and value creation in projects. To conclude, this research aims to stimulate future research into governance and innovation capabilities in project organising.

\section{Acknowledgments}

This work was supported by the Association for Project Management (APM) Research Fund.

\section{References}

Abednego, M.P. and Ogunlana, S.O. (2006), "Good project governance for proper risk allocation in public-private partnerships in Indonesia", International Journal of Project 
Management, Vol. 24 No. 7, pp. 622-634.

Ahola, T., Ruuska, I., Artto, K. and Kujala, J. (2014), "What is project governance and what are its origins?", International Journal of Project Management, Vol. 32 No. 8, pp. $1321-1332$.

Alvesson, M. and Kärreman, D. (2007), "Constructing mystery: Empirical matters in theory development", Academy of Management Review, Vol. 32 No. 4, pp. 1265-1281.

Association for Project Management (APM) (2006), Project Management Body of Knowledge (Ed), Association for Project Management, High Wycombe, UK.

Association for Project Management (APM) (2011), Directing changes: issp:A guide to governance of project management, Association for Project Management, High Wycombe, UK.

Association for Project Management (APM). (2017), Governance of project management, Association for Project Management, High Wycombe, UK.

Benítez-Ávila, C., Hartmann, A., Dewulf, G. and Henseler, J. (2018), “Interplay of relational and contractual governance in public-private partnerships: The mediating role of relational norms, trust and partners' contribution”. International Journal of Project Management, Vol. 36 No. 3, pp. 429-443.

Boddy, D. and Paton, R. (2004), "Responding to competing narratives: lessons for project managers”, International Journal of Project Management, Vol. 22 No. 3, pp. 225-233.

Brandon, P.S. and Lu, S-L. (2009), Clients driving innovation (Ed.), Wiley-Blackwell, Oxford, UK.

Brunet, M. (2018), “Governance-as-practice: Major public infrastructure projects: A case of multilevel project governing", International Journal of Project Management (in press). 
Brunet, M., and Aubry, M. (2018), “The governance of major public infrastructure projects: The process of translation”, International Journal of Managing Projects in Business, Vol. 11 No. 1, pp. 80-103.

Cardenas, I.C., Voordijk, H. and Dewulf, G. (2017), "Beyond theory: Towards a probabilistic causation model to support project governance in infrastructure projects", International Journal of Project Management, Vol. 35 No. 3, pp. 432-450.

Chakkol, M., Selviaridis, K. and Finne, M. (2018), "Governance of collaboration in complex projects", International Journal of Operations and Production Management (in press).

Chang, C.-Y. (2015), "Risk-bearing capacity as a new dimension to the analysis of project governance”, International Journal of Project Management, Vol. 33 No. 6, pp. 11951205.

Czarniawska, B. (1997), A narrative approach to organization studies, Sage Publications, London, UK.

Cunliffe, A., Luhman, T. and Boje, D. M. (2004), "Narrative temporality: Implications for organizational research”, Organization Studies, Vol. 25 No. 2, pp. 261-286.

Dailey, S. and Browning, L. (2013), "Retelling stories in organizations: Understanding the functions of narrative repetition", Academy of Management Review, Vol. 39 No. 1, pp. $22-43$

Engwall, M. and Jerbrant, A. (2003), "The resource allocation syndrome: The prime challenge of multi-project management?", International Journal of Project Management, Vol. 21 No. 6, pp. 403-409.

Enninga, T. and van der Lugt, R. (2016), “The innovation journey and the skipper of the raft: About the role of narratives in innovation project leadership", Project Management Journal, Vol. 47 No. 2, pp. 103-114. 
Frandsen, S., Kuhn, T. and Lundholt, W. (2017), Counter-narratives and organization, Routledge, New York and London.

Green, S.D. and Sergeeva, N. (2018), "Value creation in projects: Towards a narrative perspective", International Journal of Project Management (in press).

Havermans, L., Keegan, A. and Den Hartog, D. (2015), “Choosing your words carefully: Leaders' narratives of complex emergent problem resolution", International Journal of Project Management, Vol. 33 No. 5, pp. 973-984.

Hjelmbrekke, H., Lædre, O. and Lohne, J. (2014), "The need for a project governance body", International Journal of Managing Projects in Business, Vol. 4 No. 4, pp. 661-677.

Infrastructure and Projects Authority (IPA) (2016), Improving infrastructure delivery: Project initiation Routemap, Infrastructure and Projects Authority, London, UK.

Joslin, R. and Müller, R. (2015), "Relationships between a project management methodology and project success in different project governance contexts", International Journal of Project Management, Vol. 33 No. 6, pp. 1377-1392.

Klakegg, O., Williams, T., Magnussen, O. and Glasspool, H. (2008), "Governance frameworks for public project development and estimation", Project Management Journal, Vol. 39 No. S1, pp. S27-S42.

Ma, H., Zeng, S., Lin, H., Chen, H. and Shi, J.J. (2017), "The societal governance of megaproject social responsibility", International Journal of Project Management, Vol. 35 No. 7 , pp. 1365-1377.

Mayer, C. (2012), Firm Commitment, OUP, Oxford, UK.

McGrath, S.K. and Whitty, S.J. (2015), "Redefining governance: From confusion to certainty and clarity", International Journal of Managing Projects in Business, Vol. 8 No. 4, pp. 755-787. 
Miller, R. and Hobbs, B. (2005), “Governance regimes for large complex projects”, Project Management Journal, Vol. 36 No. 3, pp. 42-50.

Mishler, E.G. (1991), Research interviewing: Context and narrative, Harvard University Press, Harvard, USA.

Musawir, A.u., Serra, S.E.M. and Zwikael, O. (2017), "Project governance, benefits management, and project success: Towards a framework for supporting organizational strategy implementation”, International Journal of Project Management, Vol. 35 No. 8, pp. 1658-1672.

Müller, R. (2011), "Project governance", in P. W. G. Morris, J. Pinto and J. Söderlund, the Oxford Handbook of project management, Oxford University Press, Oxford, UK, pp. 297-320.

Müller, R., Pemsel, S. and Shao, J. (2015), “Organizational enablers for project governance and governmentality in project-based organizations", International Journal of Project Management, Vol. 33 No. 4, pp. 839-851.

Müller, R., Zhai, L. and Wang, A. (2017), “Governance and governmentality in projects: Profiles and relationships with success", International Journal of Project Management, Vol. 35 No. 3, pp. 378-392.

Müller, R., Zhai, L., Wang, A. and Shao, J. (2017), “A framework for governance of projects: Governmentality, governance structure and projectification", International Journal of Project Management, Vol. 34 No. 6, pp. 957-969.

Orstavik, F., Dainty, A. and Abbott, C. (2015), Construction innovation, John Wiley \& Sons, Chichester, UK.

Pentland, B.T. (1999), "Building process theory with narrative: From description to explanation", Academy of Management Review, Vol. 24 No. 4, pp. 711-724. 
Pentland, B.T. and Feldman, M.S. (2007), "Narrative networks: Patterns of technology and organization", Organization Science, Vol. 18 No. 5, pp. 781-795.

Ping, L., Shuping, G., Lamei, Q., Ping, H. and Xiaoyan, X. (2015), “The effectiveness of contractual and relational governances in construction projects in China", International Journal of Project Management, Vol. 33 No. 1, pp. 212-222.

Samset, K. and Volden, G.H. (2016), "Front-end definition of projects: Ten paradoxes and some reflections regarding project management and project governance", International Journal of Project Management, Vol. 34 No. 2, pp. 297-313.

Sankaran, S. (2018), "Megaproject management and leadership: A narrative analysis of life stories - past and present", International Journal of Managing Projects in Business, Vol. 11 No. 11, pp. 53-79.

Simard, M., Aubry, M. and Laberge, D. (2018), "The utopia of order versus chaos: A conceptual framework for governance, operational design and governmentality in projects", International Journal of Project Management, Vol. 36 No. 3, pp. 460-473.

Sonenshein, S. (2010), "We're changing - Or are we? Untangling the role of progressive, regressive, and stability narratives during strategic change implementation", Academy of Management Journal, Vol. 53 No. 3, pp. 477-512.

Too, E. and Weaver, P. (2014), “The management of project management: A conceptual framework for project governance", International Journal of Project Management, Vol. 32 No. 8, pp. 1382-1394.

Townsend, J. D., Balestra, S. and Schulze, A. (2017), "Characteristics of project-based alliances: Evidence from the automotive industry", International Journal of Automotive Technology and Management, Vol. 17 No. 1, pp. 8-25. 
Vaara, E., Sonenshein, S. and Boje, D. (2016), "Sources of stability and change in organizations: Approaches and directions for future research", The Academy of Management Annals, Vol. 10 No. 1, pp. 495-560.

Winch, G.M. (1998), "Zephyrs of creative destruction: Understanding the management of innovation in construction", Building Research \& Information, Vol. 26 No. 4, pp. 268279.:[5:

Winch, G.M. (2005), "Managing complex connective processes - innovation brokering”, in A. Manseau and R. Shields, Building tomorrow: Innovation in construction and engineering, Ashgate, London, UK, pp. 81-101.

Winch, G.M. (2014), “Three domains of project organising”, International Journal of Project Management, Vol. 32 No. 5, pp. 721-731.

Winch, G. and Leiringer, R. (2016), "Owner project capabilities for infrastructure development: A review and development of the 'strong owner' concept", International Journal of Project Management, Vol. 34 No. 2, pp. 271-281.

Wu, A., Wang, Z. and Chen, S. (2017), "Impact of specific investments, governance mechanisms and behaviors on the performance of cooperative innovation projects", International Journal of Project Management, Vol. 35 No. 3, pp. 504-515.

Zerjav, V., Edkins, A. and Davies, A. (2018), "Project capabilities for operational outcomes in inter-organisational settings: The case of London Heathrow Terminal 2", International Journal of Project Management, Vol. 36 No. 3, pp. 444-459.

Zwikael, O. and Amyrk, J. (2015), "Project governance: Balancing control and trust in dealing with risk", International Journal of Project Management, Vol. 33 No. 4, pp. $852-862$. 
